\title{
When You Watch Us SLeEPING
}

When you see us lying scented in our nightclothes, the patchwork quilt wadded at our feet, coverlet kicked aside, when you see us still at midnight, our bare arms covered with the moon-shadows of the hemlock by the window, our hands latent and half-open on the pillows by our heads;

When you come upon any of us buried but breathing, close to the earth, motionless as oak leaves beneath drifts of oak leaves or curled inside silk body-vases hanging from greasewood and vetch or sprawled, languid under the broad branches of the baobab in summer heat, when you hear us humming hoarsely sometimes, scarcely wheezing, murmuring like white hens at their roost;

When you watch the green anole on the banyan, cool and slender as a pod, the onyx grain of his eye closed deep in green sunlight, when you can see how he obviously possesses in his body, even in the slack scaly skin of rose beneath his jaw, even in the posing net of his ribs, even in the corpuscle of blood at the tip of his tail,

how he possesses in his body alone all the power he needs to rise and declare, not merely truth, but rapture; 
The living body asleep, so great a sum of beauty that a billion zeroes follow it, the eyes sealing the head so tightly during those moments that the infinity of possible heavens inside can be clearly perceived by anyone;

when you watch us sleeping, when you see the purest architecture of the ear, the explicit faith of the knee, the old guiltless unforgiving adoring sweet momentary tremble of claim in the breast ...

Aren't you sorry?

Don't you love us? 